\title{
Pathologic TNM Finding
}

National Cancer Institute

\section{Source}

National Cancer Institute. Pathologic TNM Finding. NCI Thesaurus. Code C48739.

TNM staging performed as part of pathologic specimen. 